\title{
Evaluation of new silvicultural alternatives for Scots pine stands in northern Spain
}

\author{
Felipe BRAVO ${ }^{\mathrm{a} *}$, Luis DIAZ-BALTEIRO ${ }^{\mathrm{b}}$ \\ ${ }^{a}$ Departamento de Producción Vegetal y Recursos Forestales, ETS Ingenierías Agrarias, Avda. Madrid 44, 34001 Palencia, Spain \\ b Departamento Economía y Gestión Forestal, ETSI Ingenieros Montes, Ciudad Universitaria s/n, 28040 Madrid, Spain
}

(Received 3 October 2002; accepted 17 July 2003)

\begin{abstract}
The new objectives which society is demanding of forest systems are leading to deep changes in their management. Aspects such as biodiversity preservation and recreation require forest management alternatives that are not based on the traditional management centered on the maximization of timber production. In this paper, we introduce five silvicultural alternatives different from those typically implemented. They are characterized by combining more intensive management practices in four cases, with the retention of a portion of the stand in the final cutting, and the extension of rotation to fulfill these non-timber producing objectives in the other case. The results for one stand of Pinus sylvestris L. in the north of Spain have been evaluated in physical terms (total volume, veneer volume), as well as in financial terms (Land Expectation Value, LEV), showing some of the alternatives its feasibility in comparison with traditional management.
\end{abstract}

silviculture / green tree retention / Pinus sylvestris L.

Résumé - Évaluation de nouvelles alternatives sylvicoles pour des peuplements de pins sylvestres dans le nord de l’Espagne. Les nouveaux objectifs que la société demande aux systèmes forestiers provoquent actuellement de profonds changements dans la gestion de ces derniers. Des aspects tels que la conservation de la biodiversité ou la jouissance récréative requièrent des modèles de gestion forestière non fondés sur la gestion traditionnelle qui est axée sur la maximisation de la production du bois. Ce travail présente cinq alternatives sylvicoles du sylviculture traditionel, qui se caractérisent, dans 4 cas, par la combinaison d'une gestion plus intensive avec la rétention d'une partie du peuplement dans la coupe finale et, dans le dernier cas, par l'extension de la rotation afin d'atteindre ces nouveaux objectifs. Les résultats pour un peuplement de Pinus sylvestris L. dans le nord de l'Espagne ont été évalués en termes de production (volume total, volume de contreplaqué) ainsi qu'en termes financiers (Valeur Potentielle du Sol, VPS), et certaines des alternatives ont montré leur viabilité par comparaison avec la gestion traditionnelle.

silviculture / rétention du peuplement / Pinus sylvestris L.

\section{INTRODUCTION}

New society demands such as wildlife conservation, water catchment area preservation and adequate landscape management are challenging forest managers around the world. One of the most important tasks in this new situation is to develop silvicultural systems close to nature with a sound scientific and economic basis. Silvicultural options such as Continuous Cover Forestry (CFC) or Green Tree Retention (GTR) are good examples of this. In some cases, intensive management can be used as a part of integrated forest management plans to stabilize the whole forest economic system.

The intention of the Green Tree Retention system is to maintain some of the trees as a lifeboat for wildlife and in this way to preserve and increase the biological diversity in forested areas. Green Tree Retention can be implemented as dispersed tree retention or as group retention. Under dispersed retention, trees selected for retention are evenly distributed over a management unit providing well-distributed large-diameter trees that can serve as a source of snags and woody debris in the future. On the other hand, group retention generates patches that can be generated in different sizes and shapes during the harvest process. A comprehensive description of these methods and their advantages and disadvantages can be found in [12]. Curtis [7] pointed out that extended rotation under traditional silvicultural practices could provide similar environmental benefits to those of GTR systems.

It is interesting to compare this type of silvicultural management, currently used in some North American forests [27] and in some European countries [19, 30], with management practices based on traditional European methods. Even-aged stands and plantations have been the greatest focus of attention for forest

* Corresponding author: fbravo@pvs.uva.es 
economics until now. Conversely, studies on GTR have mainly been concentrated on the relationship between the levels of Green Tree Retention and growth reduction [1, 18, 27, 34], structural complexity [33], and on GTR contribution to biodiversity [19]. Yet the economic implications of Green Tree Retention have been largely ignored until now.

Using inventory data, forest managers confront a task that we can divide into three different activities: (i) to develop different silvicultural alternatives for each considered stand, (ii) to evaluate each silvicultural alternative and (iii) to choose the best option with different constraints. Economic evaluation of silvicultural alternatives is crucial to implementing any sustainable forest management plan. Different silvicultural alternatives for Scots pine stands in Spain have been evaluated before $[4,13-15,26]$. However, in no case was an economic evaluation performed.

The economic effects of GTR compared with other silvicultural alternatives depend on various factors, such as: retention type (dispersed or in groups), effect on the growth of young stands [30], vegetation type, etc. Though some authors [31] claim that the interaction of the above factors can lead to varying effects, the truth is that an increase in retention after final felling causes a decrease in the financial profitability of the investment. The variability of this profitability when there are changes in the percentage of the stand retained does seem to differ among the cases that are studied: some of them show a much greater decrease at reduced retention levels [18], whereas in other issues, this decrease is showed more clearly for larger retention levels [9].

In theory, it might seem like a significant decrease in the profitability would be produced when retaining a portion of the adult forest. However, this reduction depends on the case studied. Therefore, whereas Öhman [23] quantified the decrease in the net present value (NPV) obtained when the retention of an adult forest was notable, Wikström [32] described the case of a mixed stand in which the NPV was decreased only a $3 \%$ at low levels of GTR ( $\left.20 \mathrm{~m}^{3} / \mathrm{ha}\right)$. Eid et al. [9] described a remarkable NPV reduction in an optimization problem which may include various environmental criteria as, for example, retention at the end of the rotation of 10 to 20 trees per ha, depending on the initial size and age of the private property studied. The results when this constraint is included show reductions, which can surpass $30 \%$. We must point out that in the cases studied, it is unlikely for this retention to surpass $25 \%$ of the volume of the stand at the time of felling.

As we have commented, the basic tools for achieving this stand structure in which not only productive questions exist, but also others involving the preservation of biodiversity and the landscape, etc., are the lengthening of the rotation, retention of part of the trees in final cutting and, to a lesser extent, the thinning regime and the level of mixture in the stand $[8,12,18,28]$. Though in this paper we consider alternatives that include several of these measures, in the forest management literature some studies are cited which only include modification of the optimal rotation as a variable [20]. Other works revolve around the percentage of timber retained and the kind of mixed stand [33]. Finally, other recent studies concerning silvicultural aspects of Scots pine (Pinus sylvestris L.) without including GTR can be founded in Mörling [22] and Palahi et al. [24].
The main objective of this paper is to explore the economic implications associated with Green Tree Retention, extended rotation and intensive management in Scots pine stands in northern Spain without spatial constraints and to compare the results with the traditional even-aged management alternative. The results can be used to implement sound silvicultural practices in our target forests. This paper does not include a spatial optimization in a specific forest nor does it analyze the relationships between retention (\% retained, whether disperse or in groups) and the harvesting process with the effects on the stand, as have been discussed in recent reports [17].

\section{MATERIALS AND METHODS}

Scots pine is a very important species in forestry across Europe and Siberia. In Spain, Scots pine has found its southwestern limit of distribution in mountain areas. In the wide region occupied by Scots pine, ecological and silvicultural but also economic studies are needed to ensure sustainable forest management.

The Upper Ebro Basin (northern Spain) is a transitional area between Mediterranean and Atlantic climates with altitudes ranging from 700 to $900 \mathrm{~m}$ above sea level. Scots pine dominates the vegetation community mixed with Quercus faginea Lamk, Fagus sylvatica L. and Quercus ilex L. Detailed information about the characteristics of the studied area can be found in Bravo and Montero [3, 4] and in GonzálezMartínez and Bravo [16].

Silviculture in Scots pine stands in the studied area is based on natural regeneration after shelterwood systems (22 years regeneration period); pre-commercial thinning is not frequent and thinning is reduced to self-financed interventions. Properties are mostly public (townships) and the Regional Governments are responsible for management through laws. Forest management plans have set the rotation age at 88 years. Shelterwood operations should start when stands are 88 years old and should end at 110 years. However, high-grading was extensively applied until 15 years ago. For this reason, to analyze traditional management we choose a rotation age equal to 100 years.

\subsection{Silvicultural alternatives}

Six different silvicultural alternatives have been tested, including Green Tree Retention, extended rotation, intensive management by shortened rotation and a traditional even-aged system in two site index classes. Each silvicultural alternative was implemented for two different site index classes. The classes used were 17 and $23 \mathrm{~m}$ at an age of 100 years. Bravo and Montero [3] site index curves were used. Traditional even-aged management consists of clear-cutting at 100 years of age, following natural regeneration and a low thinning regime after pre-commercial thinning to reduce density to 2000 trees/ha. The thinnings were performed at 25, 40 and 63 years in the site index class 17 and at 20, 30 y 49 years in the site index class 23 , respectively. Extended rotation is similar to traditional even-aged management, but rotation has been extended to 122 years in site index class 23 (dominant height equal to $24 \mathrm{~m}$ ) and to 137 years in site index class 17 (dominant height equal to $18 \mathrm{~m}$ ). The lengthening of rotation is also justified on ecological grounds, and to obtain trees with larger dimensions and a greater percentage of high-quality wood. Intensive management includes a shorter rotation age of 69 years in site index 23 (dominant height equal to $20 \mathrm{~m}$ ) and of 83 years in site index 17 (dominant height equal to $16 \mathrm{~m}$ ) and the same low-thinning regime as in traditional management alternative. Under these reduced rotations, one would expect to obtain greater economic benefits. Green tree aggregated retention has been implemented as the intensive management, but by retaining 25,50 and $75 \%$ of the harvest unit for the following rotations. This retained area can act as a lifeboat for different wildlife species and as 
Table I. Main characteristics of the silvicultural regimes chosen.

\begin{tabular}{|c|c|c|c|c|c|c|}
\hline & \multicolumn{3}{|c|}{ Site index 17} & \multicolumn{3}{|c|}{ Site index 23} \\
\hline & $\begin{array}{c}\text { Rotation } \\
\text { (years) }\end{array}$ & $\begin{array}{l}\text { Volume } \\
\left(\mathrm{m}^{3} / \mathrm{ha}\right)\end{array}$ & $\begin{array}{c}\text { Green Tree } \\
\text { Retained (\%) }\end{array}$ & $\begin{array}{l}\text { Rotation } \\
\text { (years) }\end{array}$ & $\begin{array}{l}\text { Volume } \\
\left(\mathrm{m}^{3} / \mathrm{ha}\right)\end{array}$ & $\begin{array}{c}\text { Green Tree } \\
\text { Retained (\%) }\end{array}$ \\
\hline Traditional even-aged management & 100 & 491.7 & 0 & 100 & 750.5 & 0 \\
\hline New intensive management 1 & 83 & 444.5 & 0 & 69 & 649.4 & 0 \\
\hline New intensive management 2 & 83 & 371.8 & 25 & 69 & 534.5 & 25 \\
\hline New intensive management 3 & 83 & 299.1 & 50 & 69 & 419.6 & 50 \\
\hline New intensive management 4 & 83 & 226.5 & 75 & 69 & 304.7 & 75 \\
\hline Long rotation management & 137 & 594.4 & 0 & 122 & 822.3 & 0 \\
\hline
\end{tabular}

Volume includes the volume at the rotation age and all the volume from commercial and precommercial thinnings.

a conservation measure to maintain biodiversity. Table I shows the main characteristics of the silvicultural regimes chosen.

All these silvicultural systems constitute a wide range of options and meet different requirements that forest managers must face today. Other methods such as dispersed tree retention or extended rotation periods under shelterwood regimes were not tested because our model does not make it possible to obtain accurate estimates in these cases. Finally, an uneven-aged structure is not usually considered for pure Scots pine stands in Spain, except in several stands between 1600 and $1800 \mathrm{~m}$ of altitude that have low stocking density [5]. Similar results are cited in Valkonen [29].

\subsection{Yield model}

A whole-stand static yield model developed by Bravo and Montero (2003) [4] was used in order to estimate timber yield under the different silvicultural alternatives. The yield model was elaborated for Scots pine stands in northern Spain using 75 temporary plots from the Second National Forest Inventory of Spain. These plots were selected to cover a wide variety of silvicultural situations. The whole-stand static yield approach was selected, because only one measurement from the plots is currently available. A multiplicative model based on the law of limiting factors was selected as a basic model form. This model form has been used previously in forest yield modeling [10, 25]. Equations for basal area $(\mathrm{G})$, mean quadratic diameter $(\mathrm{dg})$ and total volume $(\mathrm{V})$ were fitted. Each equation in the model was fitted independently. Compatibility between $\mathrm{G}$ and $\mathrm{dg}$ models was checked, and in the end the basal area equation was maintained in the model, while the mean quadratic diameter equation was discarded. The model's statistical attributes and biological consistence were evaluated in order to assure the accuracy and reliable predictions.

As the original data set includes high-graded stands, the model was calibrated by using permanent plots (Bravo and Montero, 2003) [4] to assure the accuracy of its predictions in non high-graded stands. Bravo and Montero (2001) [3] site index curves were also used. The final form of the calibrated model is:

$$
\begin{aligned}
& G=0.033 * N^{-0.107 * S D I^{1.161},} \\
& \mathrm{~V}=0.168 * \mathrm{SDI}^{0.913} * \mathrm{H}_{0}^{0.413}-215.069+15.685 * \mathrm{H}_{0}
\end{aligned}
$$

where $\mathrm{G}$ is the basal area in $\mathrm{m}^{2} / \mathrm{ha}, \mathrm{N}$ is the number of stems per ha, $\mathrm{SDI}$ is the Stand Density Index, $\mathrm{V}$ is the total volume in $\mathrm{m}^{3} / \mathrm{ha}$ and $\mathrm{H}_{0}$ is the dominant height.

The results obtained from this yield model were used on a comparative basis for the different silvicultural systems. More information about the yield model used can be found in Bravo and Montero (2003) [4].

\subsection{Economic assumptions}

The stands mentioned in this study are of public property, and their management has traditionally been oriented towards obtaining one sole benefit: timber production. In this kind of traditional management, optimization tools have not been applied, and the rotations typically used (100-120 years) ensured a level of production near the rotation that maximizes mean annual increment (MAI) in most cases, as well as the existence of logs whose final use was veneer. The price of sawtimber has traditionally been set at public auctions, which frequently leads to monopsonic practices by purchasers. This fact, coupled with a lack of reliable historical records, has had an influence on the way in which the timber price is estimated. Therefore, the choice has been made to calculate the price per cubic meter using a base price for harvest that does not produce veneer $(54.1 €)$. As the diameter of the final cut increases, the percentage of the wood that can be used for veneer increases, and consequently the final price also rises. This increase has been calculated in accordance with the work by Montero et al. [21], in which the veneer percentage is shown for each diameter class of Pinus sylvestris L. Nevertheless, a sensitivity analysis has been performed with respect to this basic price.

The consideration of some financial components such as planting costs have not been taken into account given that applied silviculture is oriented towards the existence of natural regeneration. The performance of silvicultural activities (thinning, etc.), and the signaling costs associated with final cutting were included in the analysis. Besides, we have considered a fixed cost per hectare and year of $24 €$. Finally, in this model we have chosen to use a real discount rate of $3 \%$, though a sensitivity analysis has also been carried out to show the effects of any variation in this parameter.

Because there are no stands with this kind of management, nor there are perturbations, which may be considered equivalent to this type of final cutting, as in the case of Rose and Muir [27], we have made a series of hypotheses regarding the modeling of revenues and payments caused by this new silviculture. Therefore, it is assumed that the expenses do not vary, while the revenues undergo a linear decrease as a result of the increase in harvest costs, when the percentage of Green Tree Retention is raised. This increase of harvest costs implies a timber price decrease, which reaches $30 \%$ when retention reaches a level of $75 \%$. Finally, we must point out that inaccuracies in this estimate do not affect the final result due to the length of the various rotations and the effect of discounting.

Given these assumptions, all variables and parameters involved in calculating the profitability associated with each type of silvicultural management have been described. We have evaluated each alternative on the basis of Faustmann's hypothesis, whereby the land expectation value (LEV) is calculated as the sum of cash flows, given an infinite 
Table II. Results for site index $=17 \mathrm{~m}$, considering two consecutive rotations.

\begin{tabular}{lcccrr}
\hline & $\begin{array}{c}\text { \% Gree Tree } \\
\text { retention }\end{array}$ & $\begin{array}{c}\text { LEV } \\
(€ / \mathrm{ha})\end{array}$ & $\begin{array}{c}\text { Total volume } \\
\left(\mathrm{m}^{3} / \mathrm{ha}\right)\end{array}$ & $\begin{array}{c}\text { Veneer volume } \\
\left(\mathrm{m}^{3} / \mathrm{ha}\right)\end{array}$ & $\begin{array}{c}\text { Volume retained } \\
\left(\mathrm{m}^{3} / \mathrm{ha}\right)\end{array}$ \\
\hline Traditional even-aged management & 0 & 760.2 & 983.4 & 110.2 & 0.0 \\
New intensive management & 0 & 1214.1 & 889.0 & 61.0 & 0.0 \\
& 25 & 709.1 & 705.2 & 45.8 & 30.5 \\
& 50 & 215.2 & 521.3 & 110.2 & 220.3 \\
Long rotation management & 75 & -267.3 & 337.6 & 15.3 & 330.5 \\
\hline
\end{tabular}

Total volume, veneer volume and volume retained includes the volume, the veneer and the volume retained, respectively, in the full cycle (2 rotations).

Table III. Results for site index $=23 \mathrm{~m}$, considering two consecutive rotations.

\begin{tabular}{|c|c|c|c|c|c|}
\hline & $\begin{array}{l}\% \text { Gree Tree } \\
\text { retention }\end{array}$ & $\begin{array}{l}\text { LEV } \\
(€ / \text { ha })\end{array}$ & $\begin{array}{l}\text { Total volume } \\
\left(\mathrm{m}^{3} / \mathrm{ha}\right)\end{array}$ & $\begin{array}{l}\text { Veneer volume } \\
\left(\mathrm{m}^{3} / \mathrm{ha}\right)\end{array}$ & $\begin{array}{c}\text { Volume retained } \\
\qquad\left(\mathrm{m}^{3} / \mathrm{ha}\right)\end{array}$ \\
\hline Traditional even-aged management & 0 & 2674.1 & 1501.1 & 270.3 & 0.0 \\
\hline \multirow[t]{4}{*}{ New intensive management } & 0 & 5785.0 & 1298.9 & 188.5 & 0.0 \\
\hline & 25 & 4223.7 & 1021.6 & 141.4 & 158.1 \\
\hline & 50 & 2705.2 & 744.3 & 94.2 & 316.3 \\
\hline & 75 & 1229.3 & 467.0 & 47.1 & 474.4 \\
\hline Long rotation management & 0 & 1397.0 & 1644.6 & 282.1 & 0.0 \\
\hline
\end{tabular}

Total volume, veneer volume and volume retained includes the volume, the veneer and the volume retained, respectively, in the full cycle ( 2 rotations).

chain of cutting cycles. Each cycle encloses two consecutive rotations of every silvicultural alternatives chosen. Because the stands analyzed are publicly owned, the analysis does not include a consideration of any type of tax on the income received due to final felling. Besides, none type of subsidy has been considered. Finally, even though the LEV for each alternative has been considered at a specific age, this does not mean that felling is performed right at that age. Basically, to make the analysis easier, the performance levels are grouped at this age, though in actuality shelterwood is carried out.

\section{RESULTS}

The comparison of the silvicultural alternatives described above shows differences between the various alternatives, in terms of the percentage of trees uncut and the objectives usually considered in the management of these stands: total volume, financial return and veneer volume.

Thus, Table II shows the results for site class 17, grouped by silvicultural alternatives type used. If traditional silviculture is compared with the more intensive alternatives proposed herein, one could verify that in the absence of a retained surface ( $0 \%$ Green-tree retention), financial profitability was $60 \%$ higher. This increase in land expectation value is due, in addition to the change in silvicultural management, to a reduction of the rotation length from 100 to 83 years. The gain in monetary terms is offset by a slight reduction in total volume (11\%) and a great decrease in terms of the veneer volume obtained (80\%).

Analyzing the alternatives in which the existence of an unfelled surface is allowed, it can be verified that, whereas the decreases in terms of total volume or veneer volume follow a pattern in accordance with the increase in the retention level, profitability is much more elastic when the amount of uncut area varies. Therefore, leaving $50 \%$ of the stand uncut leads to a reduction in the land expectation value of less than $25 \%$, while increasing retention to $75 \%$ leads to a negative LEV (-267.3 €/ha). In other words, for this kind of management, according to the hypotheses discussed above, the revenue obtained in both final felling and thinnings does not offset the variable costs included throughout the rotation.

Instead of choosing to retain a portion of the stand, if the manager lengthens the rotation to 137 years (long rotation management), the profitability obtained is negative $(-82.3 € / \mathrm{ha})$. This decrease is compensated by a slight increase in terms of total volume (5\% when compared with traditional handling), with a notable increase in veneer volume: $60 \%$ with respect to traditional management and a three-fold increase compared to intensive management without retention.

Table III shows the results for site class 23. It shows an increase in production caused by the improvement of ecosystem conditions for all the objectives considered in the analysis. Comparing traditional management with the more intensive silviculture with no retention proposed herein, one can verify that profitability increases by $116 \%$. On the contrary, the total volume is reduced by $16 \%$, and veneer volume goes down by $43 \%$.

Analyzing the silvicultural alternatives that include retention at the end of the rotation, they all show positive profitability. The same as with the preceding site quality, a decrease in land expectation value is produced as the percentage of retention increase, though in a more gradual manner. Therefore, leaving $75 \%$ of the surface area uncut in the first rotation leads to a reduction of LEV to somewhat less than $25 \%$. Reduction 


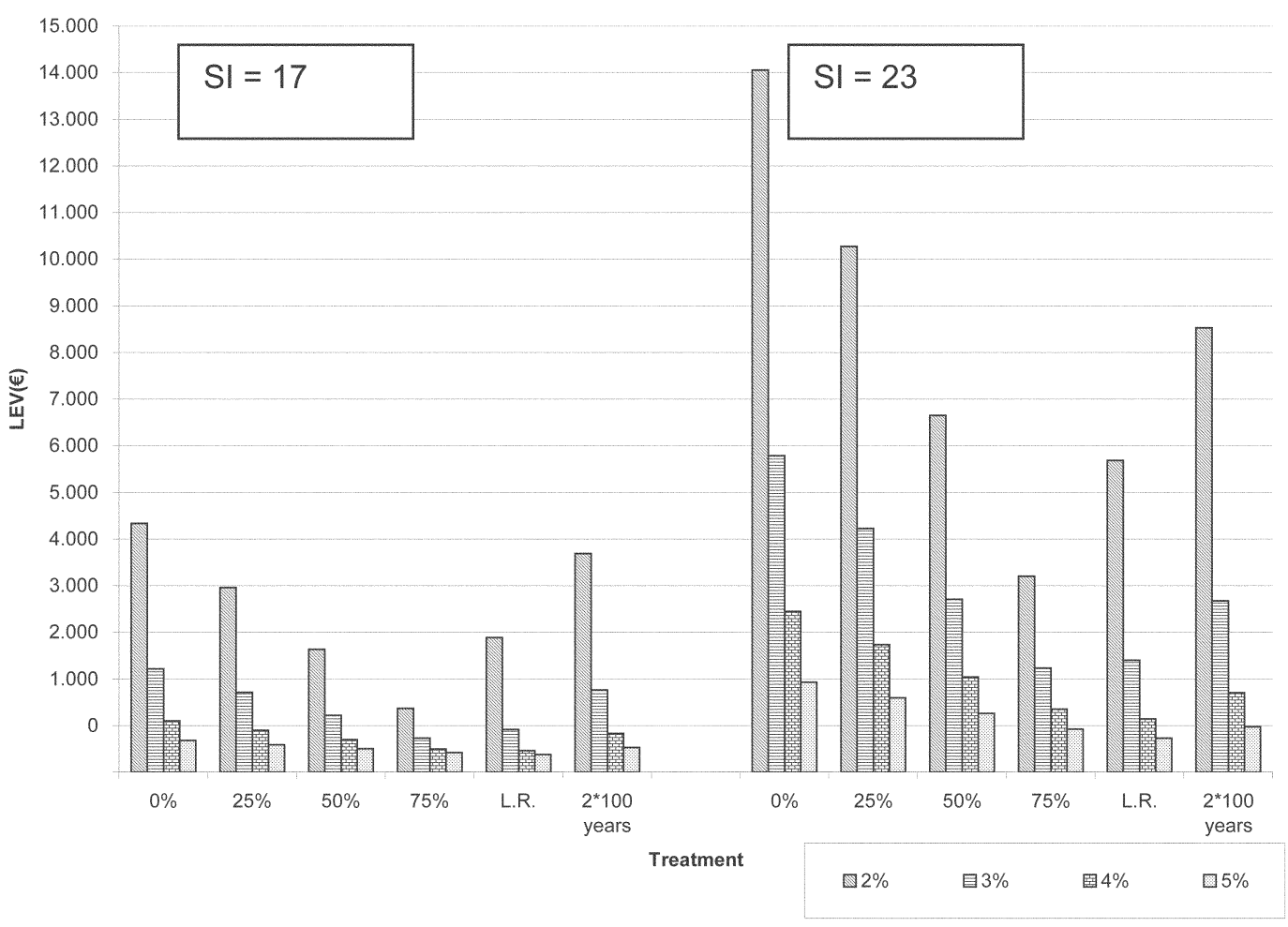

Figure 1. Land Expectation Value (LEV) for different treatment, site index and discount rate.

in terms of total volume and veneer volume follows the same trend as in site class 17.

As we have commented above, a sensitivity analysis has been performed to compare the robustness of the results obtained. The first parameter analyzed was the discount rate. In Figure 1 we show the results when the discount rate varies from 2 to $5 \%$ for site classes 17 and 23 . One can see, for site class 17 , how the established order varies in terms of the profitability of the various alternatives. Therefore, the traditional alternative is the second most preferable for an environment with social discount rates $(2 \%)$, but as the discount rate increases, from a financial perspective, the option of leaving $25 \%$ of the volume at the end of the first cutting becomes the most appealing. If we compare the alternative of lengthening the rotation with increases in the amount of wood retained we note that for discount rates of over $2 \%$, it is more appealing to retain half of the volume. Meanwhile, all alternatives show a highly elastic behavior when there are variations in the discount rate, unless we analyze the least profitable alternatives at a high discount rate $(4-5 \%)$. Though in terms of LEV variation the opposite occurs, the alternatives associated with longer rotations (traditional management, long rotation management) have the greatest elasticity in terms of absolute value.

Repeating this sensitivity analysis for site class 23 (Fig. 1), it is observed that the alternative consisting of leaving $25 \%$ of the stand uncut is always more profitable than traditional management, and except for very low discount rates, the alternative of lengthening the rotation is the least appealing of all. Likewise, we must point out the fact that, when management which includes a percentage of retention is executed, it is always profitable, regardless of the value acquired by the discount rate (except in extreme cases of maximum retention and a discount rate equal to $5 \%$ ).

Similarly, we performed a sensitivity analysis for changes in the price level considered. The results have no influence on the ordering of the alternatives proposed, regardless of site class, and show a greater lack of elasticity for the LEV when there are increases in this price level, independently if the site class or the initial price is higher.

In the same way, taking into consideration the importance traditionally given to veneer production, we have performed a sensitivity analysis to the price of veneer. It is interesting to note that veneer price increases of 50\% imply that all alternatives with retention become profitable at a lower site class. The corresponding elasticities decrease when there are small changes in veneer prices as the site class increases or when high veneer price thresholds are used.

\section{DISCUSSION}

The results presented make it possible to explore the economic influences of the silvicultural systems studied. These kinds of comparisons between silvicultural systems are very important in order to implement sound silvicultural alternatives at the practical management level. Nevertheless, the goal of this paper is not to offer a series of silvicultural alternatives, but rather to show the different options that can be used instead of traditional management, as well as their cost, depending on various 
objectives. Further research is necessary in order to assign these alternatives to the northern forests of the Iberian System, including a spatial analysis. This analysis is indispensable for handling certain outputs. For example, Finn et al. [11] found that Accipeter gentilis requirements at larger scales (around $170 \mathrm{ha}$ ) are less rigid than at stand scales. So the managers have great flexibility in balancing economic and ecologic requirements.

When the commercial value of Pinus sylvestris stands is considered, one can appreciate that the economic feasibility of the silvicultural forms that include retention can clearly compete with traditional management and even surpass it as the site class improves. In effect, while for site class 17, the LEV of traditional management is equivalent to an alternative that includes $25 \%$ retention, equivalency occurs for site class 23 when retention is doubled, only if the discount rate does not vary. This circumstance is important, because the opportunity cost of implementing this type of strategy include two highly differentiated aspects: besides the uncut wood, it is necessary to calculate the decrease in future growth of the stand.

Logically, though the economic objective is very similar when comparing these two alternatives, the same cannot be stated for the other objectives addressed by the traditional management: total volume at final harvest and veneer volume. As retention increases, this trend becomes even more notable, especially at low site classes and for veneer volume. Therefore, whereas from a financial perspective the alternative consisting of choosing $25 \%$ retention can clearly compete with traditional management at both site classes considered, it means giving up from 48 to $58 \%$ of the veneer volume foreseen in the traditional alternative.

It is also necessary to emphasize the fact that, if the introduction of a more intensive management with a form of silviculture that includes retention is considered as an option to lengthening typical management rotations, this option only seems appealing at low site classes. For example, at site class 23, if we choose to lengthen the rotation instead of continuing with traditional management implies to trade off $75 \%$ of the LEV for an increase in the final volume and veneer volume of $10 \%$ and $4 \%$, respectively.

Despite the financial cost of implementing this extensive management, numerous authors suggest its application. For instance, Curtis [7] stated that moderate extension of rotations would not decrease long-term volume production, but might well increase value production and would certainly increase aesthetic and some wildlife and biodiversity values. Carey and Curtis [6] insist that lengthening rotations within a moderate range does not lead to significant reduction of the volume obtained and, in exchange, benefits the preservation of biodiversity. The key question in this statement is what a moderate extension is. Using Rojo and Montero [26] Scots pine yield tables, we found that a 40-year extension of rotation from MAI culmination age (around 80 years old) represents between 10 and $17 \%$ of MAI reduction. Unlike the aforementioned works, both Rojo and Montero [26] and this paper deal with even-aged and pure stands. Another issue not included in this analysis is the structural complexity within the stand. Working on a Maritime pine stand in Central Spain, Bravo and Guerra [2] found over a $10 \%$ reduction of diameter at breast height growth as the stands became more complex.
The sensitivity analysis shows how the discount rate is the parameter which most notoriously affects the calculation of the LEV associates with each alternative. This circumstance is repeated in practically all of strategic forest planning models and emphasizes the paramount importance of this parameter [9]. Therefore, increases in this rate make intensive silviculture more competitive than extensive silvicultural alternatives (even-aged management, long rotation management), due to the fact that it includes shorter rotations. We should also mention the fact that even when veneer price increases $75 \%$, the alternative of lengthening the rotation is not competitive from an economic perspective, when compared with another silvicultural alternatives. In other words, the effect produced by discounting when the rotation is longer, offset the increase in the unit price of veneer volume.

One of the main problems in implementing management strategies that include measures to improve other non-wood production factors is the financial cost associated with them. Therefore, non-economists [7] argue that non-timber values (wildlife, biodiversity, amenities, etc.) are not usually considered in the LEV estimation, and that the public perception (whether justified or not) of these values are the driving force behind regulatory constraints and pressures upon forest management. Bearing in mind that the estimation of these environmental benefits requires economic methodologies (travel cost method, contingent valuation, etc.) that are being applied mainly to protected spaces and not to forest properties due to their high cost, implementing alternatives that include live tree retention at the end of the rotation could be considered by managers as a surrogate of a set of goods and services without a market price and that cannot currently be valued financially with accuracy.

It has been demonstrated in the above sections that, from an economic point of view, combinations resulting from more intensive silviculture and retention of a part of the stand can result in alternatives as appealing as those traditionally used. In this sense, a natural extension of this work would be to integrate these alternatives into different strategic and tactical planning models. Using optimization techniques or multicriteria methodologies one could more accurately evaluate the cost of implementing these silvicultural models for a specific forest and establish which are the optimal solutions for each case.

\section{CONCLUSIONS}

The results from the cases studied reveal the appropriateness of implementing more intensive forms of management, because they can clearly compete with traditional management in economic terms. However, if we analyze the effects of these alternatives on other management objectives such as total volume at final harvest, and especially veneer volume, we can see that there is a noticeable reduction in the values of these variables when these forms of management are used. Similarly, choosing more extensive solutions that involve lengthening the rotation mean giving up a large part of the economic return obtained through traditional management.

In the same way, changes in the demands of society on different goods and services related with forests make it necessary to change traditional management. Therefore, alternatives such as Green Tree Retention can maintain, increase or perpetuate 
aspects involving biodiversity, landscape, etc. Furthermore, given the lack of full cost-benefit analyses that include calculations of positive externalities produced in forests, practices like Green Tree Retention can be an example of how this change that is being produced in forest outputs demands can be integrated into forest management.

Finally, from a strictly financial perspective, and if we accept the hypotheses introduced in this paper, it has been verified that for most retention levels studied, according to the site classes analyzed, these alternatives are clearly feasible and provide sound economic results, even when the different parameters included in the LEV are modified. This circumstance cannot be claimed for silvicultural alternatives that would a priori have the same effects on goods with no market price, like those that promote longer rotations.

Acknowledgments: Comments raised by two anonymous referees have greatly improved the presentation and accuracy of this paper. Authors gratefully appreciate the constructive comments and helpful suggestions provided by Professor Carlos Romero (Technical University of Madrid). This research was undertaken with the support of the Spanish "Comisión Interministerial de Ciencia y Tecnología" (CICYT).

\section{REFERENCES}

[1] Acker S.A., Zenner E.K., Emmingham W.H., Structure and yield of two-storied stands on the Willamette National Forest: implications for green-tree retention, Can. J. For. Res. 28 (1998) 749-758.

[2] Bravo F., Guerra B., Forest structure and diameter growth in maritime pine in a Mediterranean area, in: Gadow Von K., Nagel J., Saborowski J. (Eds.), Continuous Cover Forestry, Kluwer Ac. Pub., 2002, pp. 123-134.

[3] Bravo F., Montero G., Site index estimation in Scots pine (Pinus sylvestris L.) in the High Ebro Basin (northern Spain) using soil attributes, Forestry 74 (2001) 395-406.

[4] Bravo F., Montero G., High-grading effects on Scots pine volume and basal area in pure stands in northern Spain, Ann. For. Sci. 60 (2003) 11-18.

[5] Cañellas I., Martínez García F., Montero G., Silviculture and dynamics of Pinus sylvestris L. stands in Spain, Investig. Agrar., Sist. Recur. For. 1 (2000) 233-253.

[6] Carey A.B., Curtis R.O., Conservation of bio-diversity: a useful paradigm for forest ecosystem management, Wild. Soc. Bull. 24 (1996) 610-620.

[7] Curtis R.O., The role of extended rotations, in: Kohm K.A., Franklin J.F. (Eds.), Creating a Forestry for the 21st Century. The Science of Ecosystem Management, Island Press, Washington, 1997, pp. 165-170.

[8] DeBell S.S., Curtis R.O., Harrington C.A., Tappeine, J.C., Shaping stand development through silvicultural practices, in: Kohm K.A., Franklin J.F. (Eds.), Creating a Forestry for the 21st Century, The Science of Ecosystem Management, Island Press, Washington, 1997, pp. 141-149.

[9] Eid T., Hoen H.F., Økseter P., Economic consequences of sustainable forest management regimes at non-industrial forest owner level in Norway, For. Pol. Eco. 2 (2001) 213-228.

[10] Eriksson H., Yield of Norway Spruce in Sweden, Dept. of Forest Yield Rap No. 41, 1976.

[11] Finn S.P., Marzluff J.M., Varland D.E., Effects of landscape and local habitat attirbuttes on northern Goshawk site occupancy in Western Washington, For. Sci. 48 (2002) 427-444.

[12] Franklin J.F., Berg D.R., Thornburgh D.A., Tappeiner J.C., Alternative silvicultural approaches to timber harvesting: variable retention harvest systems rotations, in: Kohm K.A., Franklin J.F. (Eds.),
Creating a Forestry for the 21st Century, The Science of Ecosystem Management, Island Press, Washington, 1997, pp. 111-139.

[13] García Abejón J.L., Tablas de producción de densidad variable para Pinus sylvestris L. en el Sistema Ibérico, Com. INIA, Ser.: Recursos Naturales, No. 10, Madrid, 1981, 57 p.

[14] García Abejón J.L., Gómez Loranca J.A., Tablas de producción de densidad variable para Pinus sylvestris L. en el Sistema Central, Com. INIA, Ser.: Recursos Naturales, No. 29, Madrid, 1984.

[15] García Abejón J.L., Tella G., Tablas de producción de densidad variable para Pinus sylvestris L. en el Sistema pirenaico, Com. INIA, Ser.: Recursos Naturales, No. 43, Madrid, 1986.

[16] González-Martínez S.C., Bravo F., Density and population structure of the natural regeneration of Scots pine (Pinus sylvestris L.) in the High Ebro Basin (Northern Spain), Ann. For. Sci. 58 (2001) 277-288.

[17] Halpern C.B., McKenzie D., Disturbance and post-harvest ground conditions in a structural retention experiment, For. Ecol. Manage. 154 (2001) 215-225.

[18] Hansen A.J., Garman S.L., Weigand J.F., Urban D.L., McComb W.C., Raphael M.G., Alternative silvicultural regimes in the Pacific Northwest simulations of ecological and economic effects, Ecol. Appl. 5 (1995) 535-554.

[19] Hazell P., Gustafsson L., Retention of trees at final harvest - evaluation of a conservation technique using epiphytic bryophite and lichen transplants, Biol. Conserv. 90 (1999) 133-142.

[20] Liu J., Cubbage F.W., Pulliam H.R., Ecological and economic effects of forest landscape structure and rotation length: simulation studies using ECOLECON, Ecol. Econ. 10 (1994) 249-263.

[21] Montero G., Rojo A., Alía R., Determinación del turno de Pinus sylvestris en el Sistema Central, Montes 29 (1992) 42-48.

[22] Mörling T., Evaluation of annual ring width and ring density development following fertilisation and thinning of Scots pine, Ann. For. Sci. 59 (2002) 29-40.

[23] Öhman K., Creating continuous areas of old forest in long-term forest planning, Can. J. For. Res. 30 (2000) 1817-1823.

[24] Palahi M., Pukkala T., Miina J., Montero G., Individual-tree growth and mortality models for Scots pine (Pinus sylvestris L.) in northeast Spain, Ann. For. Sci. 60 (2003) 1-10.

[25] Persson O.A., A growth simulator for Scots pine (Pinus sylvestris L.) in Sweden, Dept. of Forest Yield-SLU Rap. No. 31, 1992.

[26] Rojo A., Montero G., El pino silvestre en la Sierra de Guadarrama MAPA, Madrid, 1996.

[27] Rose C.R., Muir P.S., Gree-tree retention: Consequences for timber production in forests of the Western Cascades, Oregon, Ecol. Appl. 7 (1997) 209-217.

[28] Tappeiner J.C., Lavemder D., Walstad J., Curtis R.O., DeBell D.S., Silvicultural systems and regeneration methods: current practices and new alternatives, in: Kohm K.A., Franklin J.F. (Eds.), Creating a Forestry for the 21st Century. The Science of Ecosystem Management, Island Press, Washington, 1997, pp. 151-164.

[29] Valkonen S., Effect of retained Scots pine trees on regeneration, growth, form, and yield of forest stands, Investig. Agrar., Sist. Recur. For. 1 (2000) 121-145.

[30] Valkonen S., Ruuska J., Siipilehto J., Effect of retained trees on the development of young Scots pine stands in Southern Finland, For. Ecol. Manage. 166 (2002) 277-243.

[31] Vanha-Majamaa I., Jalonen J., Green tree retention in Fennoscandian forestry, Scand. J. For. Res. Suppl. 3 (2001) 79-90.

[32] Wikström P., Eriksson L.O., Solving the stand management problem under biiodiversity-related considerations, For. Ecol. Manage. 126 (2001) 361-376.

[33] Zenner E.K., Do residual trees increase structural complexity in Pacific Northwest coniferous forests? Ecol. Appl. 10 (2000) 800810.

[34] Zenner E.K., Acker S.A., Emmingham W.H, Growth reduction in harvest-age, coniferous forest with residual trees in the western central Cascade Range of Oregon, For. Ecol. Manage. 102 (1998) $75-88$. 